UDC 316.47:17.022]:94(477)

DOI: $10.21847 / 1728-9343.2019 .1(159) .157593$

OVSIANKINA LIUDMYLA,

Borys Grinchenko Kyiv University (Kyiv, Ukraine)

e-mail: l.ovsiankina@kubg.edu.ua, ORCID 0000-0002-6003-6289

\title{
CONSOLIDATING ROLE OF HISTORICAL MEMORY IN FORMATION THE MORAL FOUNDATIONS OF MODERN UKRAINIAN SOCIETY
}

The article is devoted to the analysis of the consolidating role of historical memory in forming the moral principles of modern Ukrainian society. The significance of historical memory in the development of the collective consciousness of the Ukrainian nation, the translation of all spiritual experience - knowledge of higher moral values: goodness, truth, beauty, love for freedom and justice - to the next generations is highlighted. Man and people in general are considered as the main bearers, actors and creators of historical memory. It is analyzed that the best ethical examples are created in national history as certain ways of comprehension of national interests. They are firmly fixed in historical memory and go to the historical arena in a dialectical progression - in a new form, taking into account the modern conditions of life, new pragmatic knowledge, technologies and ideas that each new generation produces.

Key words: historical memory; man; modern Ukrainian society; moral principles; consolidation.

Problem definition. The problem of historical memory as factor of uniting the past, the present and the future, consolidation of Ukrainian society and ensuring political stability is actual nowadays. This problem reflects all historical changes in our society and human conscience, shows increasing social demand for further improvement of social relations.

On the assumption of important conceptional statement of consideration of society as a system of interconnections, we can approve that historical memory of Ukrainian nation represents all historical relations inside the society, including economic, political, cultural, spiritual, moral relationships etc. As a result, each person synthesizes all historic heritage and social relations; society becomes similar to the real social and historic relations between people.

Historical memory, which blends seamless and stores in memory of Ukrainian nation, plays the great role in transmission and realization of national and social spiritual experience. In modern historical circumstances, a large number of internal and external problems connected with search and reproduction of essential spiritual and moral orientations produced in the past together with creation of new moral values, ideals and impetuses, which would provide a pillar of support to the consolidation of Ukrainian society, raise. Nowadays there is a necessity for people to have peculiar historical way of thinking that synthesizes, makes connection between past history lessons and global challenges. Ukrainian people should have a sharp awareness of the covered way, define dramatic mistakes and blissful victories in national history and in present-day developments should draw right moral conclusions for delineation of the further perspective of progressive development.

Analysis of recent studies. Famous foreign and domestic researchers have investigated the phenomenon of historical memory. P. Nora (1999), H. Blumenberg (1985),
R. Kosellek (2002), A. Megill (2007), J. Barash (2011) examine this phenomenon in different aspects: as result that is implemented in system of collective signs and is based on myths; as complicated synthesis of religious components; as result of the process of representation, reservation and replication of historical past in social consciousness. The foreign researches place special emphasis on revealing of components of historical memory, searching for its spiritual, religious and existential foundations, but the role of historical memory in consolidation of nation and assuring social integrity and consonance in the context of impetuous historical changes is not investigated deeply.

The problem of consolidation of Ukrainian transitional type society and corresponding social changes is brought up in researches of L. Huberskyj, V. Andrushchenko, M. Mikhalchenko (2004), V. Gorsky (2006), G. Kasyanov (2007), M. Popovich (2006), M. Rozumnyy (2016), M. Ryabchuk (2012), M. Stepiko (2011) and other researchers. Modern researchers point out that over the course of history Ukrainian nation underestimated the role of historical memory in strengthening of the idea of establishment of a state, democracy ideas and human rights. In Soviet period and in Independent period cultural and historical heritage have been lost gradually, what inevitably resulted in great spiritual loss for Ukrainian nation. However, in spite of complicated social and politic conditions, intergroup conflicts and identity crisis, in Ukrainian society by virtue of organization and self-organization processes psychological readiness for the dialogue, conciliation and social welfare is forming gradually.

Among many concepts of role of morality in human and social vital activity in modern scientific literature predominant are the concepts, which underline the direct axiological component. This comes from the fact that forming of a man and social development requires appearance of new spiritual and moral elements of consciousness, values and standards that help with achie- 
vement of mutual understanding and adaptation in modern historical conditions.

The majority of researchers share the following thought: the historical memory is an important attribute of selfidentification of Ukrainian nation, instrumental value and important factor of forming of national mentality. The problem of development of effective mechanism of consolidation and revealing of social needs, consolidating interests and values of Ukrainian nation remains out of consideration.

The goal of the paper is to reveal consolidating role of historical memory in forming of moral standards of modern Ukrainian society.

Presentation of the basic material. A priori man in society can be understood only in context of certain historical conditions and social relations, certain concrete historical period. A man is complicated open-circuit system that constantly remains in process of adaptation, forming and dialectical development. Personality should consciously put in order own moral rules, requirements, values and standards of given society, establish moral goals and judge independently of own actions and actions of surrounding. The moral within this meaning is the system of individual and social relations that assure functioning of society in general and each person in particular.

Many factors influence on character of assimilation of moral standards of society. Historical memory takes an important place among these factors as actual collective moral experience of the past. Individual experience - own needs, specific features, values, ideals, beliefs, personal lifestyle, - of course, are an important factor of assimilation of moral experience. This process always is too complicated, continuous and contradictory. Synthesis of historical and moral consciousness occurs subsequently. This allows a man to judge objectively historical events on the ground of formed worldview guidelines of society, common moral values and principles, putting individual sense in it and changing it to own moral standards and principles.

Problem of a man in system of moral relations takes an important place in history of philosophical thought. Philosophical tradition is represented by many historical conceptions of moral nature of a man, the essence, purpose of life and opportunities of existence. Confucius, Democritus, Aristotle, G.W.F. Hegel, I. Kant, A. Schopenhauer, K. Marx, P. Sorokin, G. Skovoroda, P. Yurkevich, M. Drahomanov, E. Fromm and others drew special attention to the moral in human life. Representatives of modern philosophical conceptions also consider that this question should not be neglected.

Certain ideal of a man characterizes each historical period. Forming of this ideal depends on historical and political changes and on changes in worldview as well. Ukraine has made the long and complicated way of its development, which is logical result of solving of different conflicts. The best spiritual and religious ideals, nationwide interests and ideas, which were produced in social consciousness and became heritage of historical memory, were essential in process of consensus searching at all times.

Among domestic personalities who made a contribution to the forming of historical memory, T. Shevchenko, who encouraged Ukrainian nation to fight against dominant class and overcome social injustice, should be mentioned. His poetry writing supported approval of national self-consciousness, ideals of freedom, justice, truth, people's will, unity and benefits. In the following, poet's romanticism together with anthropocentrism influenced of works of such Ukrainian cultural figures, as M. Drahomanov, A. Potebnja, V. Vynnychenko and others. They, in their turn, developed their own historiosophic, social and politics concepts and ideas directed to the preservation of spirituality of Ukrainian nation. The famous historian M. Drahomanov proved that personality with its intention to the moral freedom is the base of social development (Drahomanov, 1991). He considered a man and society as complicated phenomena, the development of which was determined with such factors as national mentality, history, traditions. Special attention was drawn to economic relations on which further distribution of property and all social hierarchy depended on. So, he investigated a man with moral origination and society in general in complex, interrelation and interdependence.

The position of M. Hrushevsky, another domestic historian, who considered moral, social and intellectual factors of social stabilization the most important, was peculiar. Material factors, in his opinion, influence less on forming of leading idea, "... which should dominate on mind, senses and imagination of nationality" (Hrushevsky, 1991: 159). M. Hrushevsky stressed on a necessity of close interrelation between individual and collective interests, solidarity to form great state where each person would be proud of the state. He also accented that "moral rigorisme" (Hrushevsky, 1991: 160), clear and uncompromising grounding on moral and cultural factors, moral values, spiritual and cultural needs, which should increase, are necessary to create strong, materially developed state.

In the course of historical time, when significant changes in worldview, social and economic life happen, the development of problem of a man in system of moral relations begins. The analysis of historic and philosophical materials allows embossed interpreting of theoretical works of modern philosophers on this topic.

In opinion of A. Zdravomyslov, moral values develop in society spontaneously: moral standards along with material interests pierce all spheres of social relations. "They pass into all human activity forms offering worked-out, attached by experience samples of human relations regulation" (Zdravomyslov, 1986: 180). In our view, the historical memory of nation preserves worked-out by previous generations ethical samples of regulation of human relations in structure of collective experience. A man and nation in general are major bearers, subjects and creators of historical memory. The pest ethical samples establish strongly in memory of nation and come into the historical arena in dialectical progression, in new appearance, considering new standard of living, new pragmatic knowledge, technologies and ideas produced by each new generation. Forming of historical memory proceeds exactly through the translation of knowledge of supreme moral values - goodness, truth, beauty, love for freedom and justice - to the next generation. As a result, such values are accumulated in national history as definite methods of awareness and comprehension of national interests that should be dialectically implemented into real historical events.

Famous Ukrainian philosopher V. Pazenok proposed peculiar approach to understanding of role of a man in system of moral relations and considered its main function in forming of new paradigm of justice and solidarity. In his opinion, to create a new paradigm of social existence it is essential to develop the concept of peculiarly fair human solidarity "... on condition of the alignment of solidarity and morality ... peculiar supplementation rationality with 
sensuality, intelligence with senses" (Pazenok, 1999: 150). Subjective uniting of moral and sensual with rational leads a man to its coincidence. Acceptance and practical realization of such model of behavior, in our view, requires certain moral effort from a man. That particular invariant content might become a basis of paradigm of fair solidarity and new sociality, which would be an ontological ground of new, postmodern Ukrainian society that allows perfect developing of human moral. In our opinion, this approach would facilitate state establishment and consolidation of modern Ukrainian nation, create conditions for strengthening, enrichment of its historical memory and providing with inheritance of generations.

In this context, we agree with strategy of M. Rozumnyy (2016) in sphere of social consciousness and information policy in our country on statement of conception "Ukraine common home". Author of the strategy proposes excluding any ethnic, confession or language discrimination of citizens from historical participation in social and politic life, but make citizen responsible morally for prestige of their state, its security and defending national interests (Rozumnyy, 2016).

Generally known theory of social systems allows us to investigate modern Ukrainian society in unity of all its components. According to the main principle of this theory, society is comprehensive system that develops and has its own structure, which is unity of stable interrelations between elements of system. This theory was developed by V. Arshinov, A. Bogdanov, V. Kochanowski, R. Merton, V. Mykhaylovskiy, V. Kaidalov, A. Nazaretyan, T. Parsons, I. Prigogyn, I. Stengers, A. Uyomov, H. Haken and others. In view of V. Kochanowski, the system is "general scientific concept that expresses complex of elements that are in relations with each other and with environment, what forms unity and integrity" (Kochanowski, 1999: 277). A. Bogdanov emphasized that "any organized system is preserved as far as its consuming energy are balanced with assimilation of energy from outside..." (Bogdanov, 1989: 260). On the basis of this concept we consider Ukrainian society as integral system, which consists particularly of historical memory as moral and spiritual experience of nation and part of its national history and culture.

Historical memory as important spiritual basis of society is in charge of its confident self-sufficient motion to new historical shifts. In his time, defining substance of a society, American sociologist T. Parsons used criterion that was set almost by Aristotle. The society is such type of social system among any universe of social systems, which reaches the highest level of self-sufficiency relating to its surrounding. A man as analytically independent system interacts actively with the social system. In mind of scientist, "as far as social system is created by interactions between human individuals, each participant is an actor (that has some aims, ideas, settings etc.) and an object of interaction for other actors and for one's own at the same time" (Parsons, 1993: 140). The system of interactions, on his opinion, is an aspect that appears analytically abstracted from total collection of activity processes of interaction participants. At the same time, these individuals are organisms, personalities and members of cultural systems. In our view, the inherent to the certain nation system of interaction is quintessence of nation's historical memory that consists of culture, mentality, spiritual and moral leads of society etc. This system of interaction develops in society for a long time, is kept and passed through communication to new generation that reconsiders it and restores dialectically in a changed way in new historical conditions.
So, spiritual and moral values appears an important uniting element between the society, social environment and individual, personality, the inner world. Any human interest, that appears on historical stage, get realization and reasoning in the capacity of "really human" interest that fits into the system of historical memory of nation only via moral consciousness and system of moral relations. However, inevitable divergence of private interests, moral values of particular subjects, interests and values of the state and any social formations.

The theory of social and cultural dynamics by P. Sorokin also helps in understanding of important role of a man as bearer of historical memory in system of moral relations. Major creed of this thinker is "a man is necessary and main condition of history of humanity, which is inconceivable and impossible without the man" (Sorokin, 1992: 519). P. Sorokin pointed out that maturity and fortitude of personality could be defined with presence of clear-cut moral convictions and confidence in own moral values. Due to the main thesis of this theory, we consider historical memory as basis of forming the system of spiritual and moral values and social consciousness in general. However, historically the society always have been characterized by heterogeneity through presence of large amount of subjects that have different levels of moral and culture, range of needs and interests, own views and values. These elements also determine further behavior of a man. Along with the mentioned, subjects give preferences to different models of behavior and activities. This dialectical discrepancy influences significantly on vital activity, social practice of society in general, determining its process greatly. Any historical changes in the society in any case are connected with activity of a man that is capable to establish goals and chose ways to succeed on the base of moral standards of present society. Full negation of moral values and standards by the majority of subjects of the society in all areas of its life indicates crisis state of the system in general; it emerges in chaos, uncertainty of the system and leads inevitably to the search of new values that conform with traditions of certain nation, moral stimuli and criteria in society. Therefore, transformation of moral values and standards from one historical period to another happens in such a way. The result of such selection remains in national historical memory that aims consolidation of nation and providing with political stability.

Analyzing the role of a man in society and reflecting on society consolidation scheme, famous positivist $\mathrm{H}$. Spencer in his time considered man as a center of all social relations, particularly moral. He claimed, "in order to form a correct estimate of society, it is necessary to examine the nature of individuals which it consists of" (Spencer, 1906: 24). The essence of the Spencer's theory consists in the following: historical type of a society is determined by the nature of components of its units, and each social phenomenon should have certain properties of individual, including moralities, at the bottom of it.

In our opinion, analyzing the specificity of interaction between man and society and obtaining consensus in between, we can see the following pattern: a man aiming for the need gratification enters into social, moral and other relations with other people. If the society meets the needs and requirements of the man, social relations of assertive communication and consent appears between them. In exchange, the social environment also aspires to receive estimated values of this person: shaping of the social and moral qualities, such as hard-working nature, orderliness, discipline, responsibility and so on, and practical embodi- 
ment of these qualities in different spheres of life. If it is attained, social relations of meaningful cooperation and consensus become established between people and social environment, which gives desired amenities, in response to self-organization process. When subjects of social interaction do not receive amenities from each other, relations between them become conflictual. Accordingly, social relations appear in in various capacities, but in any case, they establish on the basis of human desire of different material, economic and moral benefits and values. According aspiration is conditioned by both human and society needs. The result of this aspiration depends on mutual considering of moral principles that exist in society historically and thus are the part of historical memory.

Post-modernity concept representatives takes the stand that this conception should keep some features of art nouveau period (values of the rule-of-law state, basic rights and duties of citizens) and develop them into new synthesis of substantiality and modernization. It can be said that the historical memory provides this important synthesis in transitional historic periods of social development. Post-modernists, while analyzing transition from industrial society to post-industrial society, place great value on the spiritual, cultural and moral factors of a society and so called symbolic parties of the production. The main idea of post-modernism lies in particular in synthesis of rationalism and irrationalism. However, as Y. Astafiev states, post-modern relations are characterized with "the best pluralism, alternativeness" (Acmadp'є8, 1992: 64) in views, but in the same time there are blurring of social lines and uncertainty in expressing of own desires.

The communicative practical philosophy representatives - K.-O. Apel, D. Bohler, V. Hösle, V. Kullman, P. Ulrich, $\mathrm{J}$. Habermas - developed basic version of the modern Western European communicative paradigm and justified the value of concepts of communicative ethics of responsibility with the aim of value-based reorientation, spiritual and moral society renewal, solution to politic and ethnic conflicts, ecological problem solving. This paradigm can be used for consolidation of modern Ukrainian society. In opinion of K.-O. Apel, proposed paradigm is directed to the solution of main collision of the modern philosophy collision between analytic philosophy and existentialism, in other words, between scientism and humanism. The thinker maintained that "only the ethics, which is substantiated with transcendental and pragmatic reflection on the base of rights and duties of all members of ideal communicative community, is capable of grounding solidarity by means of equality and overall responsibility of all members of ideal communicative community" (cit. by: Yermolenko, 1999: 412). We should agree that this general consolidating moral principal of activities should come into the historical memory of the nation and consciousness of each person, become the main moral creed and come into all democratic institutions pf modern society.

Representatives of post-modernism - R. Barthes, J. Baudrillard, J.-F. Lyotard, P. Ricœur, R. Rorty, C. Castoriadis, P. Kozlowski, M. Foucault - claim that scientific and technical development are cultural and historic development, due to the fact that it is a result of representation, linguistic communication and social activities of a man throughout the course of history. Cultural development of society and moral that promotes the development in the optimal way should be in the basis and the consequence of economic, scientific and technical development. Consequently, this theory treats culture and moral in the wide sense as historical memory, as all that is created, saved and passed down through the generations during existence of different society forms and ways of world explanation.

Critically evaluating the modern world, Jean Baudrillard marked that social and historical mutation is inherent to the world. He claimed, "all humanistic criteria and values, which determined time-honored culture of moral, aesthetic, practical judgments, vanish in our system of patterns and signs" (Baudrillard, 2000: 55). Values become blurred, "simulacra" (visibility, similitude of values) lie in place of them. This process inescapable touches upon all social spheres in indetermined society. The aim of the social system in situation of social instability and historical periods of crisis is to reproduce and stabilize social unity with simultaneous displacement of all that leads to the entropy and disintegration. This process of social selforganization and regulation, in our opinion, should be grounded on strong historical memory of nation. It is capable of mustering a society to exit from inert area where stated moral values become unimportant and irrelevant.

It is worthy of note that other representative of this branch, P. Ricœur, exploring "moral" term also connects it with the concept that means inevitable part of human existence connected with standards, liabilities, interdictions that are characterized with universal requirements and enforcement effect (Ricœur, 1995: 272). Following moral standards $\mathrm{P}$. Ricœur connects with rationality requirement that generates practical intelligence. As a result, the following logical conclusion can be made: practical intelligence also is an important part of historical memory of society as indispensable feature of human activity that is connected with the moment of historical choice and realization of personal accountability and obligations to others. This capability of intelligence up to now provides possibility of realizing which criteria should dictate rules of activity to know for sure that the rule can be universal law for each person in each historical circumstances without regard to consequences.

\section{Conclusion}

The carried out analysis allows making the following conclusion: the process of adoption of moral standards $b$ of the society $y$ individual appears complicated and controversial. Many factors have influence on this process. Historical memory has a special place among them in the quality of actual moral experience of the past and individual features, needs, interests, values and special way of life. This spiritual and historical experience forms and accumulates within certain historical period, but it cannot be totally similar for the next generations because of new historical changes, appearance of new activities and increasing of pragmatism, critical view unideal past experience. In the result of the process of forming of historical memory dialectic spiral, which is relayed to the next generations in modified form, appears. A "distance" between generations is natural process that attests to alternation of generation and inevitability of course of history.

The historical memory gives an opportunity to realize individual belonging to the society and its unique history, independently receive and realize social demands, make decisions, produce own moral rules of life and evaluate concrete historical reality.

The analysis of the value of historical memory in forming of moral principles of modern Ukrainian society allows emphasizing on its consolidating role in creation 
of new stable moral ideals, strengthening of the idea of state formation, democracy and human rights. At the same time, we can trace relation back of the moral system on historical memory paradigm changes, when properties of advanced thinkers and scientists are passed to the whole society, what allows solving of practical and worldview tasks and forming of new moral ideal of a man.

Any historical changes in society in any case pass through the inner world and moral of a man. They reflect in the man's moral and historical consciousness, worldview, and correspond with personal views of the world and relations in it. However, in order to give insights into some historical event, new moral (national) idea should be apprehensible for individual and society, it should consolidate the society on new progressive actions to be learnt. Such reconsideration happens through the prism of own moral consciousness, personal aspects (needs, interests) and psychological components of a man. The idea can be implemented only when each individual feels a need in it.

Above-mentioned theme would be reflected in our further researches. An attention would be given to the mechanisms of forming of clear national idea as part of historical memory.

\section{REFERENCES}

Andrushchenko, V. P. (2006). Organizational Suspension: The Problem of Organizing and Sustaining Self-Organization in the Period of Radical Transformations in Ukraine on the Border of the Table. Experience of socio-philosophical analysis. Kiev: Atlant YUEMSi, 502 p. (in Ukrainian)

Astafiev, Y. G. (1992). Postmodernism in the cognition of society. Political studies. 3, 63-71. (in Russian)

Barash, J. (2011). On the imagination and the place of collective memory in the public sphere. Socium: Philosophical Sciences. 2, 83-96. (in Ukrainian)

Blumenberg, H. (1985). The Legitimacy of the Modern Age. Cambridge, The MIT Press, 728 p. (in English)

Bogdanov, A. A. (1989). Tectology: (Universal organizational science). Moscow: Economics, 304 p. (in Russian)

Baudrillard, J. (2000). Symbolic exchange and death. Moscow: Dobrosvet, 387 p. (in Russian)

Gorsky, V. (2006). Near sources: essays on the history of philosophical culture of Ukraine. Kyiv: Publishing House "KyivMohyla Academy", 257 p. (in Ukrainian)

Hrushevsky, M. (1991). Who are Ukrainians and what they want. Kyiv: Znannia of Ukraine, 240 p. (in Ukrainian)

Drahomanov, M. (1991). Selected ... My intention is to sketch an outline of the history of civilization in Ukraine. Kyiv: Lybid, 686 p. (in Ukrainian)

Yermolenko, A. M. (1999). Communicative Practical Philosophy. Kyiv: Libra, 488 p. (in Ukrainian)

Zdravomyslov, A. (1986). Requirements. Interests Values. Moscow: Politizdat, 233 p. (in Russian)

Kasyanov, G. (2007). The state-building process in Ukraine, 1991-2006. Political experience of independent Ukraine. Kyiv: Naukova dumka, 2007, 160-223 (in Ukrainian).

Kosellek, R. (2002). The Practice of Conceptual History: Timing History, Spasing Concepts (Cultural Memory in the Present). Stanford: Stanford University Press, 363 p. (in English)

Kokanovsky, V. (1999). Philosophy and methodology of science. Rostov n/D: Phoenix, 575 p. (in Russian)

Mikhalchenko, M. I. (2004). Ukraine as a new historical reality: European back-up player. Drohobych: VF "Vidrodzhennya", 488 p. (in Ukrainian).

Megill, A. (2007). Historical epistemology. Moscow: Kanon+, 480 p. (in Russian)
Nora, P., \& Ozuf, M., \& Puimierz, J. de, \& Vinok, M. (1999). Problematic of places of memory. In: France - memory. St.Petersburg: Publishing house of S.-Petersburg, 17-50. Retrieved from $\mathrm{http}: / / \mathrm{ec}-$ dejavu.ru/m-2/Memory-Nora.html (in Russian)

Parsons, T. (1993). The Concept of Society: Components and Their Relationships. Editorial journal "Sociology". 3-4, 137-171. (in Russian)

Popovich, M. (2006). Theory of Mentality. Problems of the theory of mentality. Kyiv: Naukova dumka, 3-30. (in Ukrainian)

Ricker, P. (1995). Around politics. Kyiv: "DL", 334 p. (in Ukrainian)

Rozumnyy, M. (2016). Challenges of national self-determination. Kyiv: NISS, 196 p. Retrieved from http://www.niss.gov.ua/content/articles/files/Rozumniy_druk-915a0.pdf (in Ukrainian)

Ryabchuk, M. (2012). From "chaos" to "stability": a chronicle of authoritarian consolidation. Kyiv: NISS, 288 p. Retrieved from https://bookland.com/download/1/10/107312/sample.pdf (in Ukrainian)

Sorokin, P. A. (1992). Man. Civilization. Society. Moscow: Politizdat, 543 p. (in Russian)

Spencer, G. (1906). Social statistics: Expression of social laws that determine the happiness of mankind. St.Petersburg: Publishing house Vrublevsky, 534 pp. (in Russian)

Stepiko, M. (2011). Ukrainian Identity: The Phenomenon and Principles of Formation. Kyiv: National Institute for Strategic Studies, $336 \mathrm{p}$. Retrieved from http://www.niss.gov.ua/content/ articles/files/ldent-62307.pdf (in Ukrainian)

Pazenok, V. S. (Ed.) (1999). Society at the dawn of the XXI century: a philosophical understanding of the flowing world. Kyiv: Ukrainian Center for Spiritual Culture, 268 p. (in Ukrainian)

\section{LIST OF REFERENCE LINKS}

Андрущенко В. П. Організоване суспільство: Проблема організації та суспільної самоорганізації в період радикальних трансформацій в Україні на рубежі століть. Досвід соціально-фрілософрського аналізу / наук. ред.: М. І. Михальченко. Киев: Атлант ЮЕмСі, 2006. 502 с.

Астафьев Я. Г. Постмодернизм в познании общества. Политические исследования. 1992. №3. С. 63-71.

Бараш Дж. О воображении и месте коллективной памяти в общественной сфрере. Социум: Философские науки. 2011. №2. C. 83-96.

Blumenberg $\mathrm{H}$. The Legitimacy of the Modern Age. Cambridge: The MIT Press, 1985. 728 p.

Богданов А.А. Тектология: (Всеобщая организационная наука). Москва: Экономика, 1989. 304 с.

Бодрийяр Ж. Символический обмен и смерть. Москва: Добросвет, 2000. 387 с.

Горський В. Біля джерел: нариси з історії філософської культури України. К.: Видавничий дім "Києво-Могилянська академія", 2006. 257 с.

Грушевський М. Хто такі українці і чого вони хочуть. Київ: Т-во "Знання" України, 1991. 240 с.

Драгоманов М. Вибране... Мій задум зложити очерк історії цивілізації на Україні. Київ: Либідь, 1991. 686 с.

Єрмоленко А.М. Комунікативна практична філософія. Київ: Лібра, 1999. 488 с.

Здравомыслов А. Потребности. Интересы. Ценности. Москва: Политиздат, 1986. 233 с.

Касьянов Г. Державотворчий процес в Україні 1991-2006. Політичний досвід самостійної України. Київ: Наукова думка, 2007. C. $160-223$.

Kosellek R. The Practice of Conceptual History: Timing History, Spasing Concepts (Cultural Memory in the Present) / trans. by T.S. Presner. Stanford: Stanford University Press, 2002. 363 p. Кохановский В. Философия и методология науки. Ростов н/Д.: Феникс, 1999. 575 с. 
Михальченко М. І. Україна як нова історична реальність: запасний гравець Європи. Дрогобич: ВФ "Відродження", 2004. 488 c.

Мегил А. Историческая эпистемология. М.: Канон+, 2007, $480 \mathrm{c}$.

Нора П., Озуф М., Пюимеж Ж. де, Винок М. Проблематика мест памяти В: Франция - пам'ять / пер. с фр.: Дина Хапаева. СПб.: Изд-во С.-Петерб. ун-та, 1999. С. 17-50. URL: http://ecdejavu.ru/m-2/Memory-Nora.html (дата звернення 28.10.2018).

Парсонс Т. Понятие общества: компоненты и их взаимоотношения. Реферативный журнал: "Социология". 1993. № 3-4. С.137-171.

Попович М. Проблеми теорії ментальності / відп. ред. М.В. Попович. К.: Наук. думка, 2006. 407 с

Рікер П. Навколо політики. К.: "Д.Л.", 1995. 334 с.

Розумний М. Виклики національного самовизначення: монографрія. М. Розумний. К.: НІСД, 2016. 196 с. URL: http://
www.niss.gov.ua/content/articles/files/Rozumniy_druk-915a0.pdf (дата звернення 23.10.2018).

Рябчук М. Від "хаосу" до "стабільності": хроніка авторитарної консолідації. К.: К.I.C., 2012. 288 c. URL: https:// bookland.com/download/1/10/107312/sample.pdf (дата звернення 23.10.2018)

Сорокин П. А. Человек. Цивилизация. Общество / пер. с англ. Москва: Политиздат, 1992. 543 с.

Спенсер Г. Социальная статистика: Изложение социальных законов, обусловливающих счастье человечества. СПб.: Изд-во Врублевского, 1906. 534 с.

Степико М. Українська ідентичність: феномен і засади формування / Національний інститут стратегічних досліджень. Київ: НІСД, 2011. 336 с. URL: http://www.niss.gov.ua/content/ articles/files/Ident-62307.pdf (дата звернення 13.10.2018).

Суспільство на порозі XXI століття: філософське осмислення плинного світу / Пазенок В. С. (ред.). Київ: Український центр духовної культури, 1999. 268 с.

Овсянкіна Людмила,

Київський університет імені Бориса Грінченка (м. Київ, Украӥна)

e-mail: l.ovsiankina@kubg.edu.ua, ORCID 0000-0002-6003-6289

\section{КОНСОЛІДУЮЧА РОЛЬ ІСТОРИЧНОЇПАМ'ЯТІ У ФОРМУВАННІ МОРАЛЬНИХ ЗАСАД СУЧАСНОГО УКРАЇНСЬКОГО СУСПІЛЬСТВА}

Стаття присвячена аналізу консолідуючої ролі історичної пам'яті у формуванні моральних засад сучасного українського соціуму. Висвітлено значення історичної пам'яті у виробленні колективної свідомості української нації, трансляції усього духовного досвіду наступним поколінням, - знань про вищі моральні цінності: добро, істину, красу, любов до свободи та справедливості. Людина і народ у цілому розглянуті як головні носії, суб'єкти і творці історичної пам'яті. Проаналізовано базові етичні принципи національної історії як певні способи усвідомлення та осмислення національних інтересів. Вони міцно закріплюються в історичній пам'яті і виходять на історичну арену в діалектичній прогресії, -у новому вигляді, враховуючи сучасні умови життєдіяльності, нові прагматичні знання, технології та ідеї, притаманні кожному новому поколінню. Доведено, що у процесі взаємодії між людиною та суспільством, а також у виникненні консенсусу між ними можна простежити таку закономірність: людина, реалізуючи свої різноманітні потреби, вступає в соціальні, моральні та інші відносини з іншими людьми; якщо суспільство йде назустріч їі бажанням та вимогам, - між ними виникають соціальні відносини позитивної взаємодії, злагоди. У свою чергу, соціальне середовище теж прагне отримати від людини деякі цінності та ресурси, - формування в неї таких морально-соціальних якостей, як працелюбство, законослухняність, дисциплінованість, відповідальність тощо та їхнє ефективне практичне втілення у різноманітних сферах життєдіяльності. Якщо це досягається, то між людьми та соціальним середовищем, яке надає їм бажані блага, завдяки процесу самоорганізації складаються соціальні відносини конструктивної співпраці та консенсусу. Якщо ж суб'єкти соціальної взаємодії не отримують один від одного бажаних благ, відносини між ними стають конфліктними. Отже, соціальні відносини виявляються у різних формах, але у будь-яких випадках вони складаються на основі прагнень людей до різноманітних матеріально-економічних й моральних благ та цінностей. Зрештою, відповідне прагнення викликається потребами як людей, так і суспільства в цілому. Акцентовано, що результат цього прагнення залежить від взаємного врахування тих моральних засад та принципів, що історично сформувалися у соціумі і стали складовою частиною його історичної пам'яті.

Ключові слова: історична пам'ять; людина; сучасний український соціум; моральні засади; консолідація.

(C) Ovsiankina Liudmyla

Надійшла до редакції: 13.11.2018

Прийнята до друку: 07.02.2019 